\title{
Erratum to: Tomato chocolate spot virus, a member of a new torradovirus species that causes a necrosis-associated disease of tomato in Guatemala
}

\author{
O. Batuman · Y.-W. Kuo • M. Palmieri •
}

M. R. Rojas • R. L. Gilbertson

Published online: 7 July 2010

(C) Springer-Verlag 2010

Erratum to: Arch Virol (2010) 155:857-869

DOI 10.1007/s00705-010-0653-9

In the original publication of this article, a new species of torradovirus was named Tomato chocolate spot virus, and the acronym ToCSV was proposed for this virus. However, this acronym has been approved by the ICTV for the begomovirus, Tomato curly stunt virus. Hence, it has been agreed that the acronym ToChSV will be used for the new torradovirus, Tomato chocolate spot virus.

The online version of the original article can be found under doi:10.1007/s00705-010-0653-9.

O. Batuman · Y.-W. Kuo - M. R. Rojas · R. L. Gilbertson $(\bowtie)$

Department of Plant Pathology, University of California Davis,

Davis, CA 95616, USA

e-mail: rlgilbertson@ucdavis.edu

M. Palmieri

Department of Plant Protection,

University of Valle de Guatemala,

Guatemala City, Republic of Guatemala 